\title{
Analysis of the economic differences between capitalist and labour-owned enterprises
}

\author{
Josefina Fernández Guadaño \\ Facultad de Ciencias Economicas y Empresariales, \\ Universidad Complutense, Madrid, Spain
}

Capitalist and

labour-owned

enterprises

679

Received June 2008

Revised October 2008

Accepted October 2008

\begin{abstract}
Purpose - In recent years, an increasing interest in the participative practices of the workpeople in their companies has taken place in the European Union. Taking advantage of this situation, the purpose of this paper is to show additional evidence of the benefits from companies with majority worker's capital participation as opposed to firms that do not follow this approach. Bearing in mind, also, that Spain is the only European country with the juridical form of financial majority participation of the workpeople, in order to recommend it in the European context according to the reached results.

Design/methodology/approach - To study whether or not there are differences in the two types of companies, a logistic regression model is used.

Findings - In this study, results indicate that business profitability (return on assets), productivity and equity capital coefficient are not significant variables for the purpose of determining the distinguishing features of labour-owned firm (LOF) as against capitalist firm. The only variable of those originally included which has turned out to be significant is the financial profitability (return on equity).

Practical implications - Initial proposal: specific European law governing investment capital of employees.

Originality/value - The study will be useful to show the characteristics of Spanish LOFs (operating under their own legal structure) and their benefits.
\end{abstract}

Keywords Return on capital employed, Spain, Business enterprise, Business analysis, Employees

Paper type Research paper

\section{Introduction}

Access of employees to ownership of the companies in which they work has been promoted for some years now in the European Union. This is a result of many studies (European Commission, 2002), which show that financial participation of employees in its various forms, such as: profit sharing, shareholding, stock options and/or asset accumulation and saving plans, boosts employees' motivation, raises productivity and improves competitiveness and profitability, as well as being a valuable instrument for raising capital.

The benefits of integrating capital and labour in the company as outlined by Morales et al. (2003, p. 20) had already been described in the nineteenth century by Mill (1879) and Jevons (1887), who concluded that employees who were also owners of their company worked harder for it and were more concerned about the quality of production because they had a more positive perception of their work, a greater sense of duty and a wish to increase their earnings, which depend on the business.

However, in order to achieve better results, employees need to be involved in areas other than the merely financial, something which can be achieved by means of participative management techniques. In other words, employees' ownership of

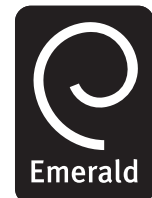

International Journal of Social Economics

Vol. 36 No. 6, 2009 pp. 679-691

(C) Emerald Group Publishing Limited 0306-8293 
IJSE

36,6

680 companies produces more positive effects on business results when combined with other measures which provide an environment in which employees can use tools, training and opportunities to play an active role in decision making (Lejarriaga Perez de Las Vacas, 2002; Vanek, 1970).

The aim of this paper is to study whether performance differences between labour-owned firm (LOF) and capitalist firm (CF) firms are due primarily to dissimilarities in capital ownership structures inherent in both types of enterprises. For these purposes, the paper is organized as follows. Section 2 outlines the European and Spanish legal framework of this context and the companies studied. In Section 3, the theoretical background, methodology and statistical data are presented, and the final two sections contain results and conclusions.

\section{Legal framework}

\subsection{European legal framework}

Employee participation in companies has been established as a key objective of European policy, as stated in different reports, recommendations and resolutions on the subject, given that the European Union (European Commission, 2002) considers financial participation of employees in companies to be one of the bases on which to build the European social model based on cooperation, with the aim of overcoming the existing dichotomy between capital and labour.

The European legal framework regarding financial participation can be divided into two long stages.

The first starts with the oldest reference that can be found in the Action Programme of the European Commission (1989) for the application of the Community Charter of Fundamental Social Rights of 5 December 1989, which outlines the creation of an instrument for shareholding and financial participation of employees.

As part of the preparation of this instrument, the European Commission (1991) launched a project which would evolve into the first PEPPER Report on promoting employee participation in profits and business results, which reviewed the situation regarding financial participation in Europe at that time.

As a result, the Council of Europe Recommendation of 27 July 1992 on the promotion of employee participation in profits and business results (including participation in its capital) invited member states to recognise the benefits of more widespread use of financial participation (European Commission, 1992).

The second PEPPER Report (European Commission, 1998), into the application of the above-mentioned recommendation, highlighted the beneficial effects of financial participation systems in terms of the increased productivity, profitability and competitiveness linked to their implementation.

The first stage ends with the European Parliament Resolution on the 1998 report. According to Terradillos Ormaetxea (2004), had this issue been regulated by a directive, the binding force of this would have established a legal base for the effective promotion of participation in shareholding by employees, through state legislation or collective negotiation.

The second stage opens with the renewed interest of the commission in the promotion of different methods of financial participation of employees in their firms, convinced that its benefits for all concerned can contribute to the attainment of the employment objectives set at the Lisbon Summit in 2001. 
This second stage starts with the commission communication to the council, the Parliament, the Social and Economic Committee and the Regional Committee "about a framework for the financial participation of employees" (European Commission, 2002), which reflects this renewed interest in employee participation schemes. Their development is potentially facilitated by the definition of a series of general principles and the promotion of concrete actions to overcome transnational obstacles impeding or limiting the introduction of PEPPER systems.

Finally, the recent incorporation of eastern European countries into the European Union was behind the third PEPPER Report of June 2006, which covers the situation regarding participation schemes in those countries (European Commission, 2006).

\subsection{Spanish legal framework}

Of the different forms of participation mentioned above, we have chosen to focus on the participation of employees in the firm's capital, with the aim of "contributing additional evidence regarding the relative significance and importance of the benefits claimed for this form of participation." At the same time, given that Spanish law provides for companies with majority financial participation by employees, we recommend this in the European context, based on the results obtained.

For this purpose, the following section briefly refers to the legal framework for the companies which will be studied here: LOFs and CFs.

2.2.1 Labour-owned firms. LOFs operate in Spain under their own legal structure, defined in Law 4 of March 1997, which has yet to be matched in any other European country (Lejarriaga Perez de Las Vacas, 2002). According to this legislation, the LOFs primary characteristic is that employees with full time, open-ended contracts with the firm must own at least 50 per cent of the LOF's capital.

Furthermore, limits are set on the number of non-partner employees on open-ended contracts with the aim of allowing them to participate if the firm grows and generates employment. With a minimum of three partners required to set-up such a company, the distribution of capital per partner is also regulated in such a way that no partner can individually own more than a third of the company's capital.

In return, in recognition of their social as well as economic purpose, LOFs enjoy fiscal advantages in the shape of tax breaks and exemptions.

2.2.2 Capitalist firms. CFs are those firms in which access to the status of partner is granted by the capital, thus becoming a means and an end in itself. Financial partnership in this type of company does not imply participation in other business processes.

The Spanish legal framework allows for different types of CF, such as the public limited and limited liability company. For the purposes of a more homogeneous study, we have chosen to focus here on the second.

Further, the limited liability company is a widely used legal formula, accounting for 25 per cent of the productive fabric of the Spanish economy as opposed to the 5 per cent represented by public companies.

The reasons for this can be found in the formulation of the law itself. Law 2/1995, 23 March 1995, governing limited liability companies allows greater flexibility for these than for public companies. The smaller sum of capital involved, the lower start-up costs, the unlimited number of partners and the ability to be personalised yet at the
Capitalist and labour-owned enterprises

681 
IJSE

36,6

682 same time a capital company are among the features of a limited liability company which make it the most appropriate legal formula for the business organisation of employees and as a vehicle for participation in the company.

\section{Theoretical framework}

Recent years have seen growing interest in the participative practices of employees in their companies, although it has to be said that this is at a very different across member states of the European Union. While some countries have a long tradition of employee participation, in others it is applied only on a small scale.

At the same time, the benefits linked to systems of financial participation by employees has been emphasised in a growing number of studies, which have provided rich empirical evidence (Cooke, 1994; Fernie and Metcalf, 1995; Batt and Appelbaum, 1995; Aghion and Tirole, 1997).

The most recent studies have shown that a greater impact on productivity and business results can be achieved if financial participation is complemented by other forms of participation, such as involvement in decision making (Jones et al., 1997; Kruse and Blasi, 1997; Poutsma, 2001; Perotin and Robinson, 2003), thus avoiding or reducing the free rider effect, or the inefficiency associated with group incentives (Oyer, 2004; Weitzman and Kruse, 1990; Poutsma et al., 2006).

Therefore, taking into account latest research (Sesil, 2006), which shows that a combination of control and rights to a share in profits of the employees bring better results for firms than if each is considered separately, it would appear that results obtained by LOFs should beat those achieved by CF. After all, the legal framework governing this context combines both social and economic rights.

Although the theoretical debate has not produced decisive results, the positive effects derived from the implementation of financial participation plans have been widely and rapidly disseminated. For this reason, we aim to find additional evidence by exploiting the fact that the LOFs in Spain are governed by a legal structure, and to recommend similar regulation in Europe.

\subsection{Choice of economic variables}

The companies in our sample are classified by whether or not they have majority participation by employees. Given that financial participation is the dependent variable, and that this can only give two results (the company either does or does not have employee participation) we will work with qualitative models, also known as discrete choice or binary. The dependent variable is coded as 0 for LOFs and 1 for CFs.

With respect to independent variables, current empirical research shows the transcendence of profitability (return on assets (ROA) and return on equity (ROE)), productivity[1] and the coefficient of equity capital[2] as variables which contribute to the differentiation of LOFs from CFs (Aghion and Tirole, 1997; Poutsma et al., 2006; Melgarejo et al., 2007).

Nevertheless, in this study, we have also chosen to include (in a second model) a greater number of economic variables[3] in order to try to improve the precision of the study and to allow us to make reliable inferences regarding the variables which turn out to be significant. 


\subsection{Methodology}

3.2.1 Description of the database. We have drawn our data from the last available year of financial statements (balance sheets and profit and loss accounts) which Spanish companies have to deposit by law, and which are publicly available in the database known as the Sistema de Análisis de Balances Ibéricos (www.bvdep.com/en/sabi.html).

Given that it was necessary to use surveys prior to carrying out the empirical study in order to check that the CFs were not actually de facto LOFs, the sample was substantially reduced. At the same time, since 82.7 per cent of LOFs are SMBs, with a size of 1 to 49 employees, we have used the criterion of size for categorisation purposes.

All told, the application of the three above-mentioned criteria (year of available data, response to the survey, and size) has left us with a sample of 270 companies of each type.

3.2.2 Statistical results. To study whether or not there are differences in the two types of companies, a logistic regression model has been used in an attempt to analyse the variables which influence the probability that a company does or does not have employee participation.

The regression model with a dependent binomial (logistic or logit model) (Hair et al., 2006), is a model which will allow us to study whether the discrete variable, in our case the financial participation of employees, does or does not depend on other variables.

\section{Results obtained}

There are two distinct methods of introducing variables, giving rise to two different models:

(1) Introduction method (Model 1). The independent variables are introduced into the model in a single step without checking entry criteria.

(2) Step-by-step method (Model 2). The independent variables are introduced into and then eliminated from the model one by one.

\subsection{Model 1 (introduction method)}

In Model 1, the four independent variables which in previous studies have shown a greater discriminatory capacity for the dependent variable are introduced: financial profitability (ROE), economic profitability (ROA), productivity, and the equity capital coefficient.

The following results were obtained. Using the $\chi^{2}$-statistic, the global significance hypothesis is tested to see whether the coefficients of the model as a whole are statistically different from 0 (Table I).

In this case, the 0.000 value of the associated $p$-value indicates that the null hypothesis can be rejected. It is accepted that the coefficients of the model are statistically different from 0 .

\begin{tabular}{lccrr}
\hline & $\chi^{2}$ & Gl. & Sig. & \\
\hline Step 1 & & & & \\
Step & 79.700 & 4 & 0.000 & Table I. \\
Block & 79.700 & 4 & 0.000 & Omnibus test of model \\
Model & 79.700 & 4 & 0.000 & coefficients \\
\hline
\end{tabular}

Capitalist and labour-owned enterprises

683 
IJSE

36,6

684

Table II.

Abstract's models
Table II shows different measures of the goodness-of-fit of the model. The verisimilitude algorithm is a measure of the verisimilitude of the results obtained from the estimated parameters. The following two measures indicate the percentage of variance explained by the model. Cox and Snell's $R^{2}$ is a general coefficient used to estimate the proportion of variance of the dependent variable explained by the independent variable; Negelkerke's $R^{2}$ is a corrected version of Cox and Snell's $R^{2}$ which adjusts the scale from 0 to 1 , thus avoiding the fact that even in a perfect model values of below one can occur, as is the case in Cox and Snell's $R^{2}$. In our study, low values for both measures is taken in Model 1.

Table III allows us to interpret the fit of the model. In total, 148 out of 268 LOFs were classified correctly (55.2 per cent), as were 221 CFs out of 269 (82.9 per cent). In total, 68.7 per cent of businesses were correctly classified.

In the logit model, in contrast to the linear multiple regression model, the estimated parameters cannot be interpreted directly (Lévy Mangin and Varela Mallou, 2003), given that the relationship between the explanatory variables and the probability of occurrence in not linear. In practice, only the direction of the estimated parameters is interpreted. Thus, depending on whether the parameter is positive or negative, when the value of the explanatory variable increases the probability of the event under scrutiny increases or decreases, respectively. In our case, the only variable which turns out to be significant is financial profitability (ROE), which is negatively linked to the CFs and positively linked to the LOFs. It is the only factor which helps to differentiate the behaviour of the latter with regard to the former.

Therefore, in Table IV it can be observed with a confidence level of 95 per cent, that only one independent variable, financial profitability (ROE), is significant. This analysis shows that there are irrelevant variables which could be eliminated, and therefore a model based on a step-forward method is constructed.

\begin{tabular}{cccc}
\hline Step & $-2 \log$ verisimilitude & Cox and Snell's $R^{2}$ & Negelkerke's $R^{2}$ \\
\hline 1 & $664.739^{\mathrm{a}}$ & 0.138 & 0.184
\end{tabular}

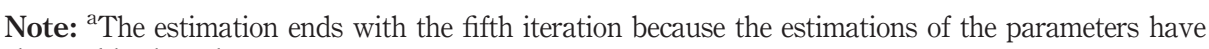
changed by less than 0.001
Table III.

Classification table

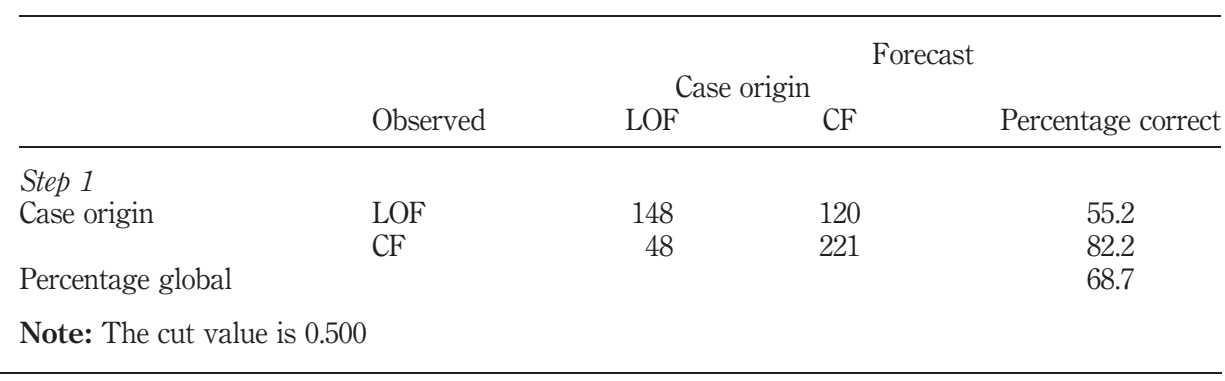




\subsection{Model 2 (step-by-step)}

The previous analysis is completed using a step-by-step variable selection method in order to eliminate variables which can be considered irrelevant to thus obtain a simpler model. That is to say, due to the results of Model 1 not being as favourable as expected (low goodness-of-fit, low probability of accuracy), we opt for a step-forward logistic regression model using the "Wald" selection criterion, or "Wald's methodology".

In the step-forward selection method, we start with a model with no variables, just the constant. The first variable to be introduced is the one with the $p$-value linked to the statistic with the lowest score, as long as this value is inferior to a pre-determined critical value. At each step, the variable can be eliminated if it meets the exit criterion. The exit criterion is established in relation to verisimilitude or Wald's statistic, in such a way that if the associated $p$-value is higher than a predetermined critical value, the variable is eliminated from the model. And so, one by one, the variables are introduced or rejected depending on whether or not they meet the entry and exit requirements, until the moment when none of the variables yet to be introduced into the model meet the entry criteria and none of the variables in the model meet the exit criteria.

Summarizing the Wald forward method, we start from a null model and consider those variables which are significant. The results obtained are as follows: just as before, using the $\chi^{2}$ the global significance hypothesis of the model is tested. In this case, the associated $p$-value shows that the null hypothesis can be rejected and the fact that the coefficients are statistically different from 0 can be accepted (Table V).

Table VI shows the different goodness-of-fit measures of the model. The verisimilitude logarithm should fall at each step, while $R^{2}$ should rise, given that the measures are ordered chronologically and have been improved step-by-step.

The estimation of parameters is carried out by the method of maximum verisimilitude.

Given that this is not a linear model for the estimation of parameters, an iterative algorithm needs to be applied, in this case the estimation ends with seven iterations because the estimations of the parameters change by less than 0.001 .

Table VII allows us to interpret the fit of the model. Of a total of 223 LOFs, 184 have been correctly classified, which accounts for 82.5 per cent. Equally, 175 CFs of 236, or 74.2 per cent, are correctly classified. Thus, the global fit is 78,2 per cent, and this represents a substantial improvement on the previous model.

The procedure followed after this, as summarised in Table VIII, consist of introducing a variable into the model when $p$-value of the score statistic, measuring the amount of improvement in the model after introduction, is below 0.05. Once the

\begin{tabular}{lrrrrrr}
\hline & \multicolumn{1}{c}{$B$} & ET & Wald & Gl. & Sig. & $\operatorname{Exp}(B)$ \\
\hline Step $1^{\text {a }}$ & & & & & & \\
Productiv. & 0.000 & 0.001 & 0.011 & 1 & 0.915 & 1.000 \\
Return on assets & -0.001 & 0.004 & 0.070 & 1 & 0.792 & 0.999 \\
Return on equity & -0.010 & 0.002 & 33.218 & 1 & 0.000 & 0.990 \\
Coefficient of equity capital & 0.322 & 0.194 & 2.763 & 1 & 0.096 & 1.380 \\
Constant & 0.479 & 0.117 & 16.610 & 1 & 0.000 & 1.614
\end{tabular}

Note: ${ }^{a}$ Variable(s) introduced in Step 1: PRODUCTI, RETURNA, RETURNE, COEFCAPI
Capitalist and labour-owned enterprises

685 


\begin{tabular}{|c|c|c|c|c|}
\hline \multirow{6}{*}{$\begin{array}{l}\text { IJSE } \\
36,6\end{array}$} & & $\chi^{2}$ & Gl. & Sig. \\
\hline & Step 1 & & & \\
\hline & Step & 59.773 & 1 & 0.000 \\
\hline & Block & 59.773 & 1 & 0.000 \\
\hline & Model & 59.773 & 1 & 0.000 \\
\hline & Step 2 & & & \\
\hline \multirow{16}{*}{686} & Step & 67.665 & 1 & 0.000 \\
\hline & Block & 127.428 & 2 & 0.000 \\
\hline & Model & 127.428 & 2 & 0.000 \\
\hline & Step 3 & & & \\
\hline & Step & 13.145 & 1 & 0.000 \\
\hline & Block & 140.573 & 3 & 0.000 \\
\hline & Model & 140.573 & 3 & 0.000 \\
\hline & Step 4 & & & \\
\hline & Step & 13.462 & 1 & 0.000 \\
\hline & Block & 154.025 & 4 & 0.000 \\
\hline & Model & 154.025 & 4 & 0.000 \\
\hline & Step 5 & & & \\
\hline & Step & 6.459 & 1 & 0.011 \\
\hline & Block & 160.485 & 5 & 0.000 \\
\hline & Model & 160.485 & 5 & 0.000 \\
\hline & Step 6 & & & \\
\hline \multirow{3}{*}{$\begin{array}{l}\text { Table V. } \\
\text { Omnibus test of model } \\
\text { coefficients }\end{array}$} & Step & 3.634 & 1 & 0.031 \\
\hline & Block & 164.118 & 6 & 0.000 \\
\hline & Model & 164.118 & 6 & 0.000 \\
\hline
\end{tabular}

\begin{tabular}{lccc}
\hline Steps & $-2 \log$ verisimilitude & Cox and Snell's $R^{2}$ & Negelkerke's $R^{2}$ \\
\hline 1 & $576.536^{\mathrm{a}}$ & 0.122 & 0.163 \\
2 & $508.881^{\mathrm{b}}$ & 0.242 & 0.323 \\
3 & $495.736^{\mathrm{a}}$ & 0.264 & 0.352 \\
4 & $482.284^{\mathrm{c}}$ & 0.285 & 0.380 \\
5 & $475.825^{\mathrm{d}}$ & 0.295 & 0.393 \\
6 & $472.191^{\mathrm{d}}$ & 0.301 & 0.401
\end{tabular}

Table VI.

Abstract's models
Notes: The estimation ends with the ${ }^{\mathrm{a}} 4 \mathrm{th},{ }^{\mathrm{b}} 5 \mathrm{th},{ }^{\mathrm{c}} 6$ th and ${ }^{\mathrm{d}} 7$ th iteration because the estimations of the parameters have changed by less than 0.001 , respectively

variable has been introduced into the model, the system checks if it meet, the exit criterion, in such a way that the variable is rejected if the verisimilitude statistic has an associated $p$-value of over 0.10 .

After introducing the variables into the model, the individual significance test is carried out on the parameters, so that:

$H_{0} . \beta_{j}=0$. The parameter is equal to 0 .

$H_{1} . \beta_{j} \neq 0$. The parameter is not 0 .

where $j=1, \ldots, n$; each parameter. 


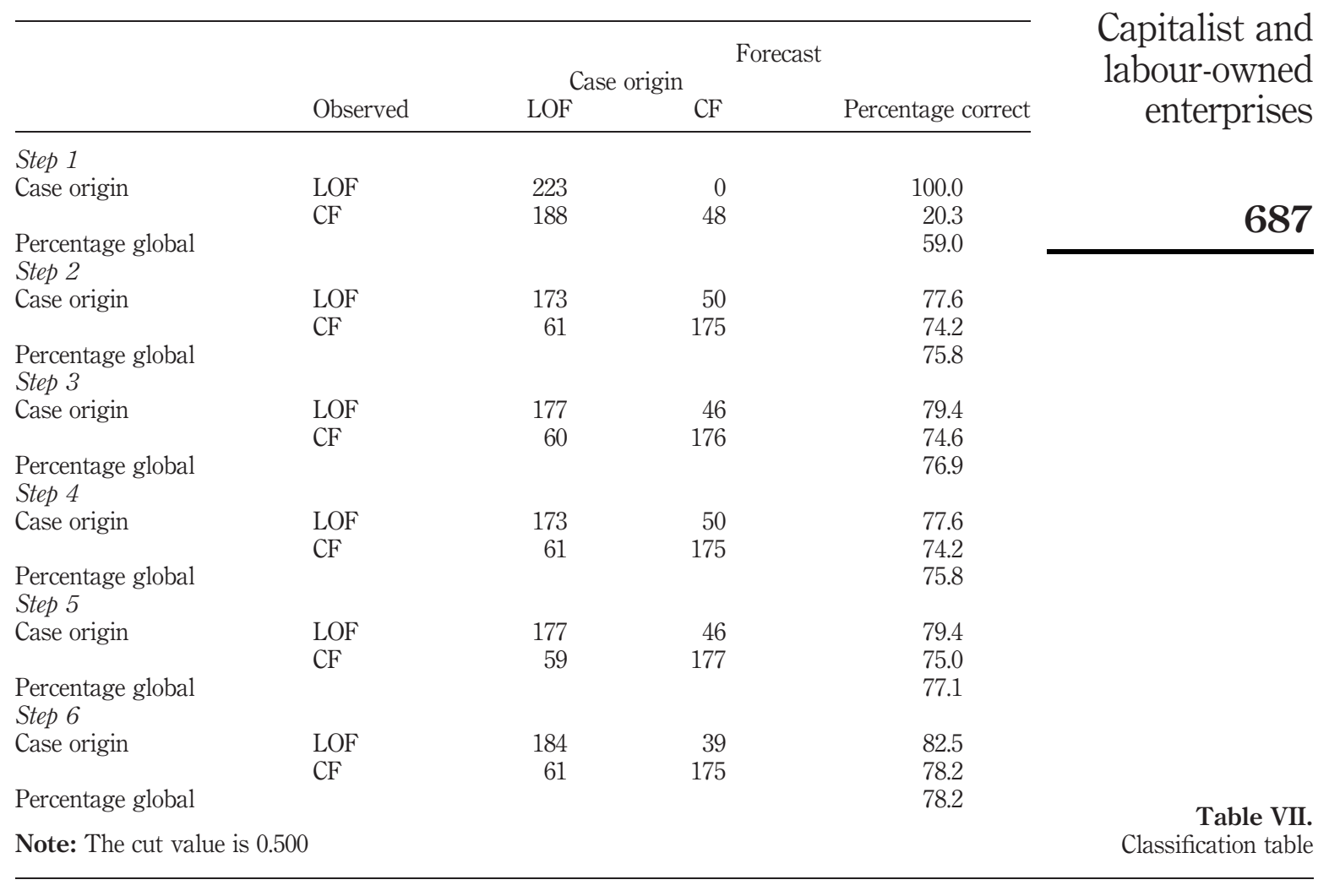

Table VIII shows that the coefficients associated with all the variables is significant to a degree of significance of 5 per cent. Given that the associated $p$-values are below 0.05 the null hypothesis that the parameters are not statistically different from 0 can be rejected. Thus, the value of the associated odds ratio is different to 1 and it follows that the analysed variables produce changes in the likelihood of occurrence and therefore cannot be eliminated from the model.

The odds ratio is defined as the variation of the likelihood of occurrence of the event (quotient between $P(Y=1) / P(Y=0)$ ). This value is the factor by which the likelihood of occurrence of the event under study is multiplied when the associated variable is increased by one in the case of numerical variables.

The value of $\exp (B)$, which provides the estimated odds ratio, with values of below one indicates the chance of possibility 1 occurring is smaller than the occurrence of possibility 0 . In our study, a rise in treasury, yearly profits, value added and financial profitability (ROE) increases the probability that the company has majority employee participation.

On the other hand, if the ratio is greater than one, Option 1 is more likely than Option 0. In our case, a rise in equity capital and operating revenue reduces the probability that the company has majority employee participation. 


\section{IJSE \\ 36,6}

688

\begin{tabular}{|c|c|c|c|c|c|c|}
\hline & $B$ & ET & Wald & Gl. & Sig. & $\operatorname{Exp}(B)$ \\
\hline \multicolumn{7}{|l|}{ Step 1} \\
\hline $\begin{array}{l}R O E \\
\text { Step } 2\end{array}$ & \\
\hline Operat. revenue & 0.001 & 0.000 & 39.387 & 1 & 0.000 & 0.987 \\
\hline \multirow{2}{*}{\multicolumn{7}{|c|}{ Step 3}} \\
\hline & & & & & & \\
\hline Equity capital & 0.001 & 0.001 & 4.356 & 1 & 0.037 & 1.001 \\
\hline Operat. revenue & 0.001 & 0.000 & 19.836 & 1 & 0.000 & 1.001 \\
\hline$R O E$ & -0.012 & 0.002 & 40.043 & 1 & 0.000 & 0.988 \\
\hline \multicolumn{7}{|l|}{ Step 4} \\
\hline Equity capital & 0.004 & 0.001 & 10.506 & 1 & 0.001 & 1.004 \\
\hline Operat. revenue & 0.001 & 0.000 & 13.326 & 1 & 0.000 & 1.001 \\
\hline Y. profit & -0.007 & 0.002 & 11.594 & 1 & 0.001 & 0.993 \\
\hline \multirow{2}{*}{\multicolumn{7}{|c|}{ Step 5}} \\
\hline & & & & & & \\
\hline Treasury & -0.004 & 0.002 & 5.553 & 1 & 0.018 & 0.996 \\
\hline Equity capital & 0.005 & 0.001 & 14.294 & 1 & 0.000 & 1.005 \\
\hline Operat. revenue & 0.001 & 0.000 & 16.777 & 1 & 0.000 & 1.001 \\
\hline$Y$. profit & -0.008 & 0.002 & 14.117 & 1 & 0.000 & 0.992 \\
\hline$R O E$ & -0.012 & 0.002 & 38.173 & 1 & 0.000 & 0.988 \\
\hline \multicolumn{7}{|l|}{ Step 6} \\
\hline Treasury & -0.004 & 0.002 & 5.737 & 1 & 0.017 & 0.996 \\
\hline Equity capital & 0.006 & 0.001 & 15.504 & 1 & 0.000 & 1.006 \\
\hline Operat. revenue & 0.001 & 0.000 & 17.186 & 1 & 0.000 & 1.001 \\
\hline Y. profit & -0.007 & 0.002 & 8.208 & 1 & 0.004 & 0.993 \\
\hline Value added & -0.002 & 0.001 & 3.443 & 1 & 0.005 & 0.998 \\
\hline ROE & -0.011 & 0.002 & 34.912 & 1 & 0.000 & 0.989 \\
\hline
\end{tabular}

Table VIII.

Variables in the equation
Notes: Variable(s) introduced in Step 1: ROE; Step 2: OPERATREV; Step 3: ECAPITAL; Step 4: YPROFIT; Step 5: TREASURY; Step 6: VADDED

In summary, this model achieves an accuracy rating of 78.2 per cent and has a moderate fit of 0.4 for Nagelkerke's $R^{2}$. The results presented above allow us to infer that they are the result of the different business management policies in both types of companies.

One of the distinguishing features of the business and financial behaviour of LOFs compared to CFs is a greater preference for liquidity. In line with Martín López's (2007, p. 540) findings, this may be due to a preference for a more conservative sales policy, with cash payment or short-term credit with the aim of minimizing the chances of bad debt. Furthermore, greater available resources give them the opportunity to generate more cash with which to meet short-term commitments to third parties.

The yearly profit and added value variables have also helped to differentiate LOFs from $\mathrm{CFs}$, while the operating revenue variable is more favourable for $\mathrm{CFs}$, which could be due to the greater cost-control capacity attributable to LOFs in line with Melgarejo et al.'s (2007) findings.

Finally, we can link the equity capital variable, which is favourable for CFs, to the annual profit and financial profitability (ROE) variables, which are favourable for LOFs, because it is possible to infer from these results that LOFs manage to obtain better results for their partners from their own resources through better business performance. 


\section{Conclusions}

The initial aim of this study was to propose regulation through a specific European law governing "investment capital of employees" which any business organisation could turn to and which could improve the possibilities of employee participation, backed up by results of the present study.

This is not a new idea and has been included in the report on the Commission communication to the Council, the Parliament, the Social and Economic Committee and the Regional Committee about a framework for the financial participation of employees (European Commission, 2002), but what is new here is the proposal to regulate a European LOF, taking the Spanish LOF as a reference model for businesses with majority employee participation.

However, the results produced by the statistical data are not as good as could have been hoped in order to support this proposal. In this study, we can conclude from the hypotheses raised, which have been tested in other studies referred to in the theoretical framework, that the Model 1 results indicate that business profitability (ROA), productivity and equity capital coefficient are not significant variables for the purpose of determining the distinguishing features of LOFs as against CFs. The only variable of those originally included which has turned out to be significant is that of financial profitability (ROE).

Having said this, however, of the significant variables which contribute to the differentiation of both types of firm, Model 2 allows us to distinguish a preference for liquidity and better business performance as measured by annual profits, added value, cost control and greater profitability on equity capital.

\section{Notes}

1. Productivity (last year $)=($ Revenues - Consumption of goods and raw materials - Other business costs//Wages.

2. $\mathrm{CCP}=$ Equity capital/Total liabilities.

3. Tangible and intangible assets, current assets, treasury, total assets, equity capital, total liabilities, working capital, net income, gross result, ordinary result before taxes, result of the exercise (yearly profit), personnel expenses (wages), cash flow, value added, earnings before interest and taxes, earnings before interest, taxes, depreciation and amortization, indebtedness, capacity of return, general liquidity, immediate liquidity, solvency ratio, profit for employee, average cost of employee, equity capital for employee, and total assets for employee.

\section{References}

Aghion, P. and Tirole, J. (1997), "Formal and real authority in organizations", Journal of Political Economy, Vol. 105, pp. 1-29.

Batt, R. and Appelbaum, E. (1995), "Worker participation in diverse settings: does the form affect the outcome, and if so, who benefits?", British Journal of Industrial Relations, Vol. 33 No. 3 , pp. 353-78.

Cooke, W.N. (1994), "Employee participation programmes, group based incentives and company performance: a union-nonunion comparison", Industrial and Labour Relations Review, Vol. 47 No. 4, pp. 594-609.
Capitalist and labour-owned enterprises

689 
IJSE

36,6

690

European Commission (1989), "Communication from commission concerning its action programme relating to the implementation of the community charter of basic social rights for workers", COM (89) 569 Final, Brussels, 29 November.

European Commission (1991), The PEPPER Report: Promotion of Employee Participation in Profits and Enterprise Results in the Member States of the European Community, Directorate-General Employment, Industrial Relations and Social Affairs, Luxembourg.

European Commission (1992), Council Recommendation of 27th July 1992 Regarding the Promotion Among Member States of Employee Participation in the Profits and Business Results of Companies (Including Shareholding).

European Commission (1998), Resolution of 15th January 1998 Concerning the Second PEPPER Report on the Promotion Among Member States of Employee Participation in the Profits and Business Results of Companies (Including Shareholding), COM(1998) 697.

European Commission (2002), European Parliament Resolution Relating to the Commission Communication to the Council, the Parliament, the Social and Economic Committee and the Regional Committee Regarding a Framework for the Financial Participation of Employees (COM(2002) 364 - (2002/2243(INI)).

European Commission (2006), The PEPPER III Report: Promotion of Employee Participation in Profits and Enterprise Results in the New Member and Candidate Countries of the European Union, Institute for Eastern European Studies, Free University of Berlin, Berlin, 353 pages.

Fernie, S. and Metcalf, D. (1995), "Participation, contingent pay, representation and workplace performance: evidence from Great Britain", British Journal of Industrial Relations, Vol. 33 No. 3, pp. 279-315.

Hair, J.F., Black, B., Babin, B., Anderson, R.E. and Tatham, R.L. (2006), Multivariate Analysis, Prentice-Hall, New York, NY.

Jones, D., Kato, T. and Pliskin, J. (1997), "Profit sharing and gain sharing: a review of theory, incidence and effects", in Lewin, G., Michell, D. and Zaide, M. (Eds), The Human Resource Management Handbook, Part I, JAI Press, Greenwich, CT, pp. 153-74.

Kruse, D. and Blasi, J. (1997), "Employee ownership, employee attitudes, and firm performance: a review of the evidence", in Lewin, G., Michell, D. and Zaide, M. (Eds), The Human Resource Management Handbook, Part I, JAI Press, Greenwich CT, pp. 113-51.

Lejarriaga Perez de Las Vacas, G. (2002), "Participación financiera de los trabajadores y creación de valor: una propuesta operativa de comportamiento con relación a los objetivos empresariales", CIRIEC-España, Vol. 40 No. 2, pp. 73-98.

Lévy Mangin, J.P. and Varela Mallou, J. (Directores) (2003), Análisis Multivariable para las Ciencias Sociales, Pearson Prentice-Hall, Madrid.

Martín López, S. (2007), Estudio analítico de las implicaciones del pago único de la prestación por desempleo particularizado para las Sociedades Laborales madrileñas, Universidad Complutense, Madrid.

Melgarejo, Z., Arcelus, F.J. and Simon, K. (2007), "Accounting for profitability: differences between capitalist and labour-owned enterprises", International Journal of Social Economics, Vol. 34, pp. 485-501.

Morales, A.C., Monzón, J.L. and Chaves, R. (2003), "La empresa autogestionada en retrospectiva", in Morales, A.C., Monzón, J.L. and Chaves, R. (Eds), Análisis económico de la empresa autogestionada, CIRIEC-España, Valencia, pp. 7-47.

Oyer, P. (2004), "Why do firms use incentives that have no incentive effects?", Journal of Finance, Vol. 59 No. 4, pp. 1619-41. 
Perotin, V. and Robinson, G. (2003), Participation of Profit and Ownership: A Review of Issues and Evidence, European Parliament, Luxemburg.

Poutsma, E. (2001), Recent Trends in Employee Financial Participation in the European Union, European Foundation for the Improvement of Living and Working Conditions, Dublin.

Poutsma, E., Kalmi, P. and Pendleton, A. (2006), "The relationship between financial participation and other forms of employee participation: new survey evidence from Europe", Economic and Industrial Democracy, Vol. 27 No. 4, pp. 637-67.

Sesil, J.C. (2006), "Sharing decision-making and group incentives: the impact on performance", Economic and Industrial Democracy, Vol. 27 No. 4, pp. 587-607.

Terradillos Ormaetxea, E. (2004), "Iniciativas comunitarias para la promoción de la participación (financiera y otras) en la empresa", in Landa Zapirain, J.P. (Cood), Nuevas formas de participación de los trabajadores y gobierno de la empresa, Albacet, Bomarzo, pp. 55-68.

Vanek, J. (1970), The General Theory of Labor Managed Marked Economies, Cornell University Press, Ithaca, NY.

Weitzman, M. and Kruse, D. (1990), "Profit sharing and productivity", in Blinder, A. (Ed.), Paying for Productivity: A Look at the Evidence, Brookings, Washington, DC, pp. 95-141.

\section{Further reading}

Bonin, J.P., Jones, D.C. and Putterman, L. (1993), "Theoretical and empirical studies of producers co-operatives: will ever the twain meet?", Journal of Economic Literature, Vol. 31 No. 3, pp. 1290-320.

\section{Corresponding author}

Josefina Fernández Guadaño can be contacted at: jfernandezguadao@ccee.ucm.es

To purchase reprints of this article please e-mail: reprints@emeraldinsight.com Or visit our web site for further details: www.emeraldinsight.com/reprints 
Reproduced with permission of the copyright owner. Further reproduction prohibited without permission. 